\title{
二相ステンレス鋼管の液相拡散接合法の開発
}

\author{
堀尾浩次 ${ }^{*}$, 山田龍三* , 冷水孝夫*
}

\section{Development of the Transient Liquid-Phase (TLP) Diffusion Bonding Process for Duplex Stainless Steel Tubes}

\author{
Hirotsugu Horio, Ryuzo Yamada, and Takao Shimizu
}

\section{Synopsis}

The transition liquid-phase (TLP) diffusion bonding process was recently tailored to join the tubes of duplex stainless steel, Fe-25Cr-6.5Ni-3Mo-2W-0.5Cu-0.3N, with a Ni brazing filler, $\mathrm{Ni}-7 \mathrm{Cr}$-3Fe-4.5Si-3B. The butts cramped by a hydraulic system are heated up locally with an induction coil in Ar shield gas. While the bonding at the holding temperatures lower than $1250^{\circ} \mathrm{C}$ introduces a large amount of boron nitrides at the interface which degrade extremely the tensile strength of the joint, the higher temperature bonding eliminates them from the joint, whose strength is about 850MPa close to $1000 \mathrm{MPa}$ for the base metal. The coarser recrystalized grains in the stronger joint scatter the ultrasonic wave so significantly that the joint efficiency is judged non-destructively with the ultrasonic transmission test. The precipitates Fe-Cr-Mo $X$ in HAZ reduce substantially the impact value of the joint, which recovers to the original level after the post-heat treatment at $1100^{\circ} \mathrm{C}$ to dissolve them. Another precipitates $C_{7} C_{3}$ in $H A Z$ don't impair the localized corrosion and the stress corrosion cracking resistance. The developed TLP process is a promising technology for joining the duplex stainless steel tubes at the site of oil fields.

\section{1 . 緒 言}

油田・ガス田などに使用される材料は，谷の使用環境下 に合わせて選定されており，一般の腐食環境下で用いられ る炭素鋼から厳しい腐食環境下で使用される $\mathrm{Ti}$ 合金まで 種々の材料が用いられている.二相ステンレス鋼は, オー ステナイト系ステンレス鋼の欠点である塩化物環境での 応力腐食割れに優れ，また，硫化物環境においても高い抵 抗性を持っているので, 近年, 油田・ガス田などに広く用 いられている.

油井管は全長数千メートルに及び，管を締結する技術が 不可欠であり，カップリングやプレミアムジョイント 1),2) と言われるネジ継手と，GTAW，SMAW，GMAW 法など による溶接継手が使用されている.しかし，温度および圧 力が高い環境において圧縮・引張応力を絶えず強く受ける ので,ネジ継手ではネジが緩み, ガス洩れが発生する問題
点を抱えている .一方, 溶接継手においては, 溶接材料の 開発が進み, 良好な継手が得られている ${ }^{3), 4)}$ が, 溶接にお いても入熱条件, 積層数, パス間温度, ビード表面の性状 など管理項目が多く，高度な溶接技術が必要とされる．

液相拡散接合法は材料端面間にインサート材を挿入し， 高周波誘導加熱装置により接合部を母材溶融以下の温度 に加熱し，低融点のインサート材のみを溶融させて，イン サート材の元素が母材に拡散して接合する方法である .こ の接合法は短時間接合が可能で接合能率が高く，操作が簡

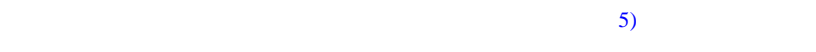
動車部品の接合 ${ }^{6), 7)}$ や鉄筋バーの接合 ${ }^{8)}$ に用いられている. そこで, 油田・ガス田現場における二相ステンレス鋼の 接合に，この簡便な液相拡散接合法の適用を図るため，二 相ステンレス鋼の液相拡散接合継手の性能を調査した . 


\section{2 . 実験方法}

\section{1 供試材料}

本実験に使用した二相ステンレス鋼管およびインサー 卜材の化学成分を Table 1 に示す.二相ステンレス鋼の母 材は外径 $178 \mathrm{~mm}$ ，板厚 $13.8 \mathrm{~mm}$ で冷間仕上げされた鋼管 であり，インサート材は ,ニッケルろう材BNi-2(JIS Z 3265) 相当の厚さ $40 \mu \mathrm{m}$ の䇴を接合面寸法・形状に加工したも のを用いた .

\section{2 液相拡散接合実験条件}

Fig.1 に接合実験装置の模式图を示す.図に示すように， 接合面にインサート材を挿入し，油圧シリンダを用いて接 合面を加圧し，接合部を $180 \mathrm{~s}$ 間アルゴンガスで置換した 後，高周波誘導法を用いて接合部近傍のみを加熱した .な お，高周波誘導加熱装置は出力 $200 \mathrm{~kW}$, 周波数 $3 \mathrm{kHz}$ であ る . 接合部の温度は誘導加熱コイルに装置した放射温度計 で計測・制御し，接合温度を一定に保持した。併せて，円 周方向の接合部の温度の安定性を確認するために熱電対 による温度測定を実施した。 Table 2 に接合条件を示す．

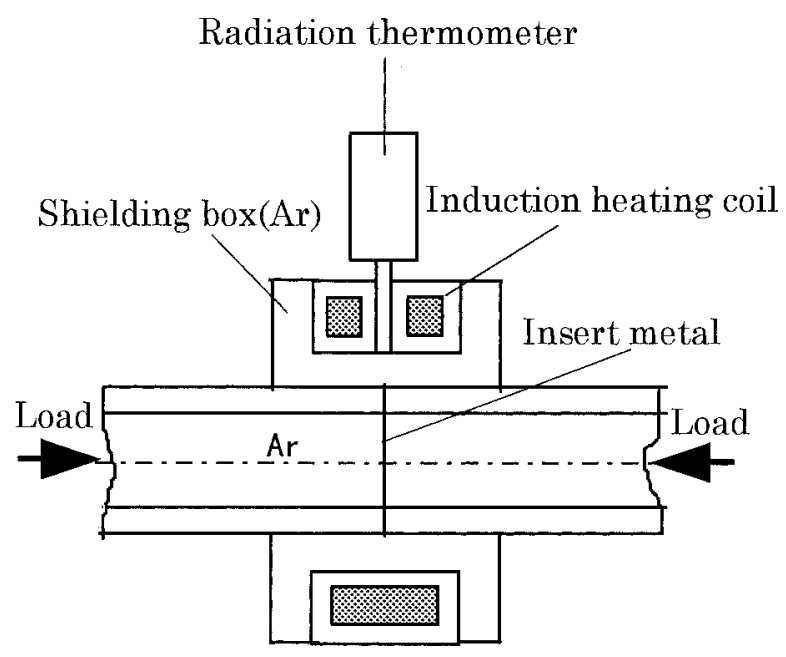

Fig . 1 . Schematic diagram of bonding equipment.

Table 2. Bonding condition of duplex stainless steel.

\begin{tabular}{l|c}
\hline Bonding temperature $\left({ }^{\circ} \mathrm{C}\right)$ & $1100-1350$ \\
\hline Holding time $(\mathrm{s})$ & $30-300$ \\
\hline Bonding pressure $(\mathrm{MPa})$ & $2.0-4.0$ \\
\hline Bonding surface roughness (Rmax. $\mu \mathrm{m})$ & $5-45$ \\
\hline
\end{tabular}

\section{3 後熱処理}

二相ステンレス鋼の溶接継手の熱影響部に $\sigma$ 相などの析 出物が析出し ${ }^{4)}$, 衝撃特性が低下することが知られている ので, 本実験では, 一部の接合継手に対して, 熱影響部の 衝撃特性を向上させることを目的として, 接合後, 固溶体 化処理 $\left(1100^{\circ} \mathrm{C} \times 900 \mathrm{~s} \rightarrow\right.$ 水冷 $)$ を実施した .

\section{4 接合継手特性評価}

\section{4 .1 接合継手の機械試験および内質調査}

適正な液相拡散接合条件を得るため, Table 2 に示す条件 で接合した接合継手の引張試験を実施し，Table 3 に示す 接合条件を選定した。光して, 石油掘削部材に必要な基本 特性を確認するため, 選定した接合条件を用いて液相拡散 接合した二相ステンレス鋼接合継手の側曲げ試験，接合部 の硬さ試験，および，熱影響部（接合界面から $50 \mathrm{~mm}$ の部 位）のシャルピー衝撃試験（接合まま，および，後熱処 理) を実施した . 各種機械試験片の形状を Fig.2 に示す． 硬さ試験はマイクロビッカース (荷重 4.9N) で長手方向 に $1 \mathrm{~mm}$ 間隔で実施した .

また，内質調査として，接合部のミク口組織観察，接合 界面の EPMA，および，熱影響部の抽出物の $\mathrm{X}$ 線回折実 験を実施した 。

Table 3. Bonding condition of duplex stainless steel to research some properties.

\begin{tabular}{|c|c|}
\hline Bonding temperature $\left({ }^{\circ} \mathrm{C}\right)$ & 1300 \\
\hline Holding time $(\mathrm{s})$ & 60 \\
\hline Bonding pressure ( $\mathrm{MPa})$ & 2.7 \\
\hline Bonding surface roughness (Rmax. $\mu \mathrm{m}$ ) & $<10$ \\
\hline
\end{tabular}

\section{4 .2 接合継手の腐食試験}

接合部の耐食性を評価するため,二相ステンレス鋼接合 継手の 4 点曲げ応力腐食割れ試験 ,および, 局部腐食試験 を実施した . 各種腐食試験片の形状をFig.3 に示す . 接合 部の試験片は接合界面を中心に採取し，熱影響部の試験片 は接合界面から $50 \mathrm{~mm}$ の部位を中心として採取した .

応力腐食割れ試験はオートクレーブ内でTable 4 に示す 条件で実施した ·試験終了後,割れなどの欠陥を確認する ため, 目視観察，断面ミクロ組織観察，および，SEM 観 察を実施した。

局部腐食試験はオートクレーブ内でTable 5 に示す条件

Table 1 . Chemical compositions of base metal and filler metal (mass \%).

\begin{tabular}{l|c|c|c|c|c|c|c|c|c|c|c|c|c}
\hline & $\mathrm{C}$ & $\mathrm{Si}$ & $\mathrm{Mn}$ & $\mathrm{P}$ & $\mathrm{S}$ & $\mathrm{Ni}$ & $\mathrm{Cr}$ & $\mathrm{Mo}$ & $\mathrm{Cu}$ & $\mathrm{W}$ & $\mathrm{N}$ & $\mathrm{B}$ & $\mathrm{Fe}$ \\
\hline Base metal & 0.018 & 0.25 & 0.41 & 0.005 & 0.001 & 6.54 & 25.05 & 3.21 & 0.54 & 2.03 & 0.29 & - & Bal. \\
\hline Insert metal & 0.022 & 4.14 & - & 0.005 & 0.002 & Bal. & 6.68 & - & - & - & - & 3.0 & 3.20 \\
\hline
\end{tabular}


で実施した ·試験終了後，割れなどの欠陥を確認するた め，目視観察，断面ミク口組織観察，および，SEM 観察 を実施した .

(a)

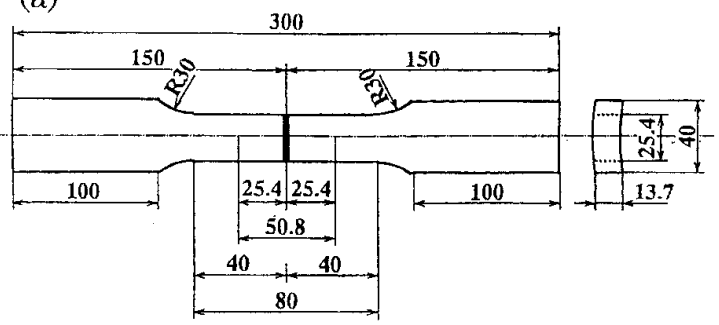

(b)

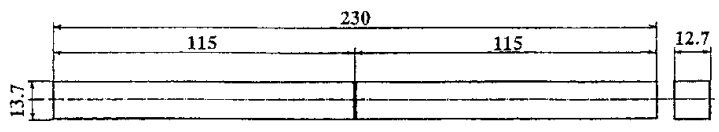

(c)
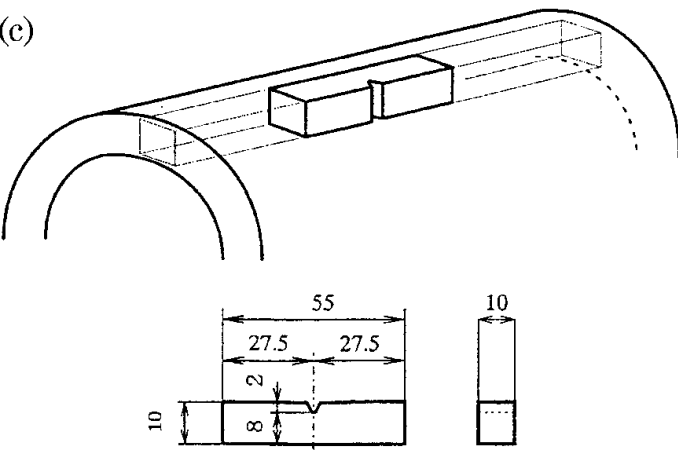

Fig. 2. Dimension of mechanical test specimen of base metal, bonded joint, and HAZ. (a) Tensile test specimen. (b) Side-bend test specimen. (c) Charpy impact test specimen.

(a)

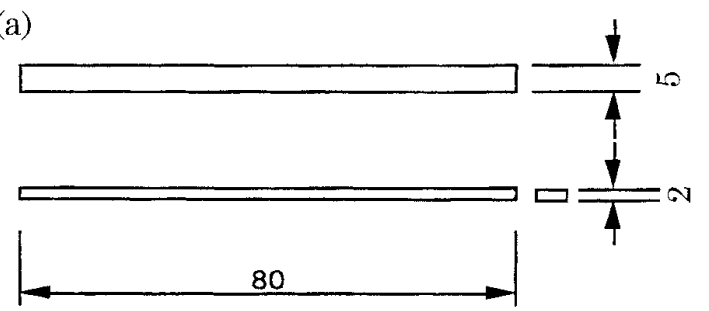

(b)

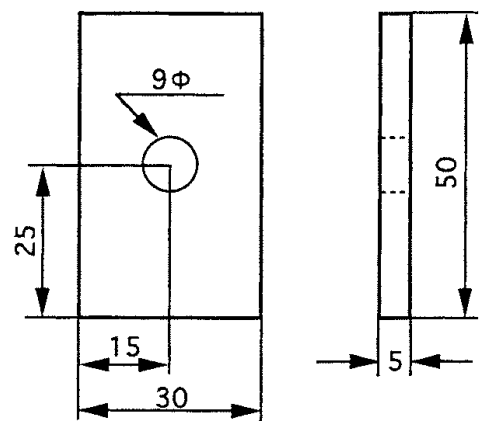

Fig. 3. Dimension of corrosion test specimen of base metal, bonded joint and HAZ. (a) Four point bending stress corrosion cracking test specimen. (b) Localized corrosion test specimen.
Table 4. Four point bending stress corrosion cracking test condition of bonded joint of duplex stainless steels.

\begin{tabular}{l|c}
\hline Testing solution & $25 \% \mathrm{NaCl}$ \\
\hline Atmosphere gas & $1.12 \% \mathrm{H}_{2} \mathrm{~S}+\mathrm{CO}_{2}(7 \mathrm{~atm})$ \\
\hline Testing temperature $\left({ }^{\circ} \mathrm{C}\right)$ & 110 \\
\hline Testing time $(\mathrm{h})$ & 720 \\
\hline Stress $(\mathrm{MPa})$ & 588 \\
\hline
\end{tabular}

Table 5. Localized corrosion test condition of bonded joint of duplex stainless steels.

\begin{tabular}{l|c}
\hline Testing solution & $25 \% \mathrm{NaCl}$ \\
\hline Atmosphere gas & $1.12 \% \mathrm{H}_{2} \mathrm{~S}+\mathrm{CO}_{2}(7 \mathrm{~atm})$ \\
\hline Testing temperature $\left({ }^{\circ} \mathrm{C}\right)$ & 200 \\
\hline Testing time $(\mathrm{h})$ & 2160 \\
\hline
\end{tabular}

\section{5 接合部の非破壊検査}

非破壊て接合界面の接合状態を評価するため，二相ステ ンレス鋼接合継手の超音波探傷試験を行った . Fig.4 に示 すように ,2 スキップの直射法と4スキップによる透過法 を用いて実施した . 超音波探触子としては，屈折角 20.6 度, 振動数 $5 \mathrm{MHz}$, 振動子サイズ $10 \mathrm{~mm} \times 10 \mathrm{~mm}$ の縦波斜 角探触子を用い，接触媒質としてマシン油を使用した .超 音波探傷試験後 ,二相ステンレス鋼接合継手のミクロ組織 観察，および，引張試験を実施した。

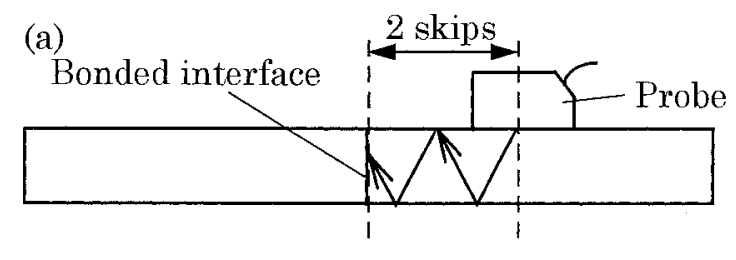

(b) 4 skips

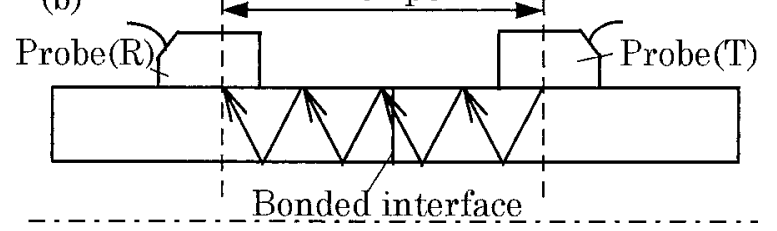

Fig. 4. Schematic diagram of ultrasonic testing. (a) Reflection technique. (b) Through transmission technique.

\section{3 . 実験結果}

\section{1 液相拡散接合条件の選定}

Table 2 に示した各種の条件で接合した二相ステンレス 鋼接合継手の引張強さに及ぼす接合温度の影響をFig.5に 示す 接合温度が高くなるにつれて, 引張強さが増加した . 二相ステンレス鋼接合継手の引張強さに及ぼす保持時 
間の影響をFig.6に示す . 保持時間が長くなるほど，接合 継手の引張強さは低下する傾向か認められた .

接合圧力については，Fig.7 に示すように接合温度が $1250{ }^{\circ} \mathrm{C}$ 以下の場合 , 接合圧力が高いほど接合継手の引張 強さは低下する傾向が認められた . 接合温度 $1250^{\circ} \mathrm{C}$ 以上 では, 接合圧力が $2.0 \mathrm{MPa}$ から $3.0 \mathrm{MPa}$ の範囲で, 弚の接 合継手の引張強さは熱影響部と同等であった .

二相ステンレス鋼接合継手の引張強さに及ぼす接合面 粗さの影響を Fig.8 に示す．同図には，接合温度 $1300{ }^{\circ} \mathrm{C}$, 保持時間 $60 \mathrm{~s}$, 接合圧力 $2.5 \mathrm{MPa}$ における接合継手の引張 強さを示したが, 本実験範囲内では引張強さに及ぼす接合 面粗さの影響は認められなかった .

以上の結果から，二相ステンレス鋼の液相拡散接合条件 として，Table 3 に示す条件を選定した．次に，選定した 接合条件で接合した二相ステンレス鋼接合継手の諸特性 を調査した .

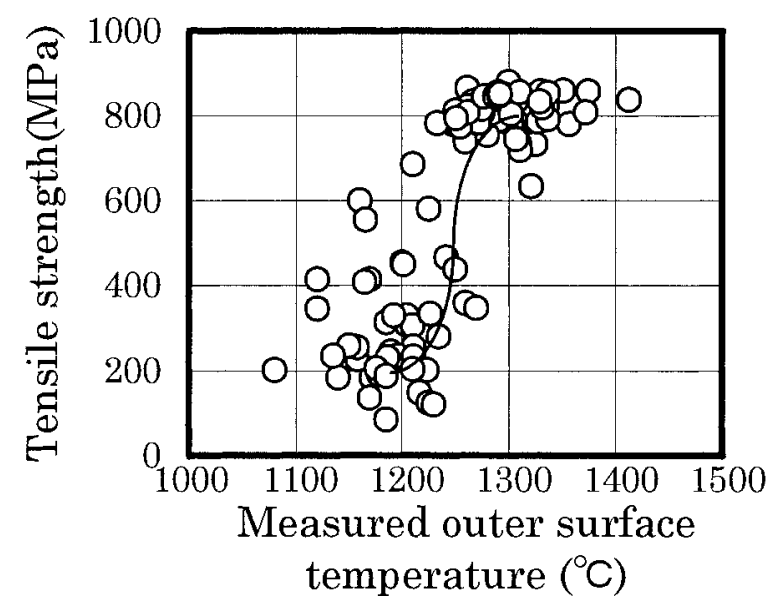

Fig. 5. Effect of bonding temperature on tensile strength of bonded joint of duplex stainless steels.

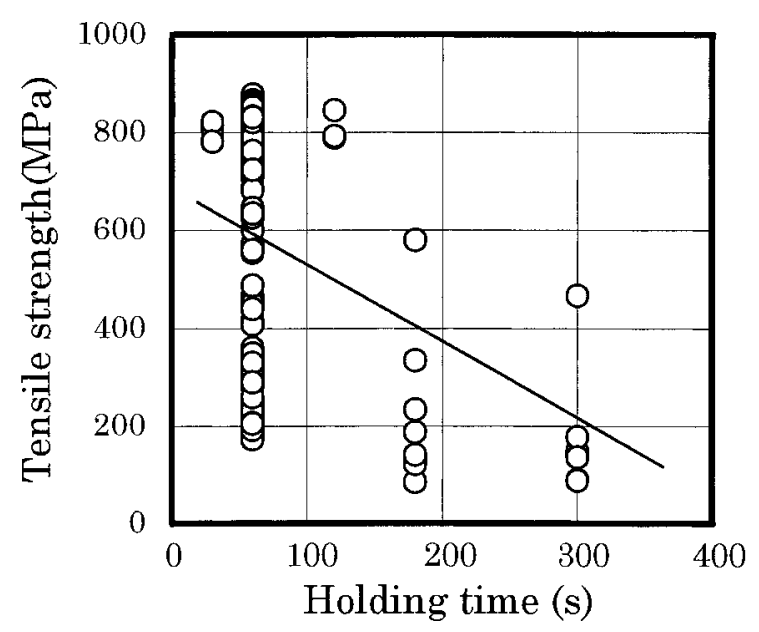

Fig. 6. Effect of holding time on tensile strength of bonded joint of duplex stainless steels.

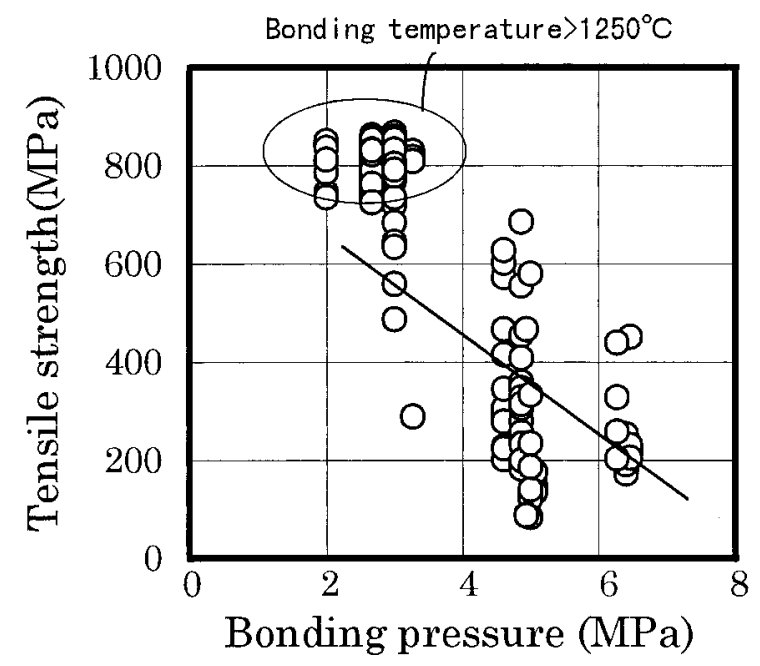

Fig. 7. Effect of bonding pressure on tensile strength of bonded joint of duplex stainless steels.

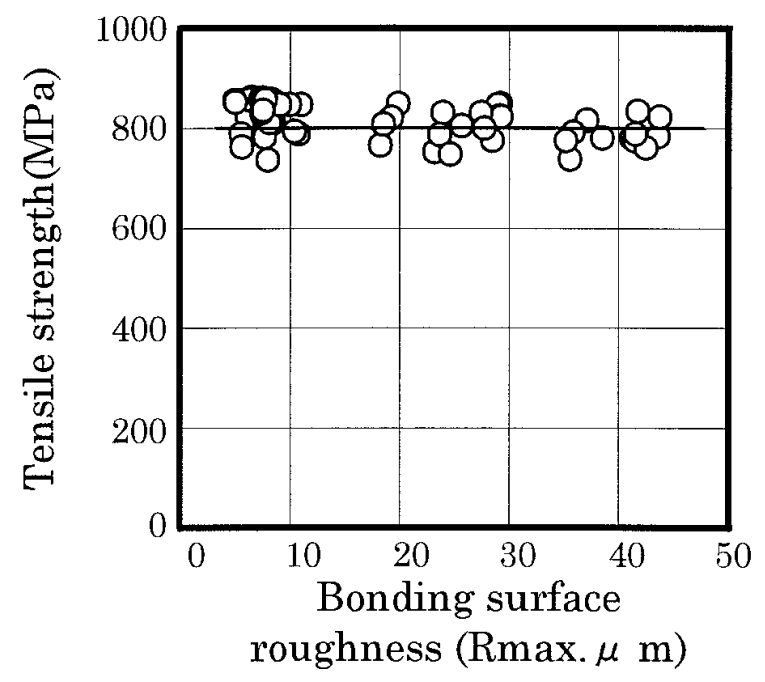

Fig. 8. Effect of bonding surface roughness on tensile strength of bonded joint of duplex stainless steels.

\section{2 選定した液相拡散接合条件を用いた 接合継手の機械特性および内質調査 結果}

\section{2 .1 接合継手の引張試験結果}

二相ステンレス鋼接合継手の引張試験の結果を Table 6 に示す.接合継手の破断位置は熱影響部であり，引張強さ は約 850MPa と母材の約 1000MPa と比べ低いものの, 伸 びは約 30\% と母材の約 20\% に比べ，高い值を示した .

\section{2 .2 接合継手の側曲げ試験の結果}

二相ステンレス鋼接合継手の側曲げ試験の結果例を Fig.9 に示す．接合継手は破断することなく約 $180^{\circ}$ 曲げ られたが, 接合継手の最大曲げ荷重は母材のものに比べ, 
Table 6. Results of tensile strength of bonded joint of duplex stainless steels.

\begin{tabular}{c|c|c|c}
\hline Specimen & Tensile strength(MPa) & Elongation(\%) & Fractured portion \\
\hline \multirow{3}{*}{ Base metal } & 1002 & 18.1 & Base metal \\
\cline { 2 - 4 } & 1000 & 16.6 & Base metal \\
\cline { 2 - 4 } & 1028 & 17.1 & Base metal \\
\hline \multirow{2}{*}{ Bonded joint } & 857 & 30.9 & HAZ \\
\cline { 2 - 4 } & 859 & 32.3 & HAZ \\
\cline { 2 - 4 } & 855 & 33.2 & HAZ \\
\hline
\end{tabular}

約 $10 \mathrm{kN}$ 低い値を示した .

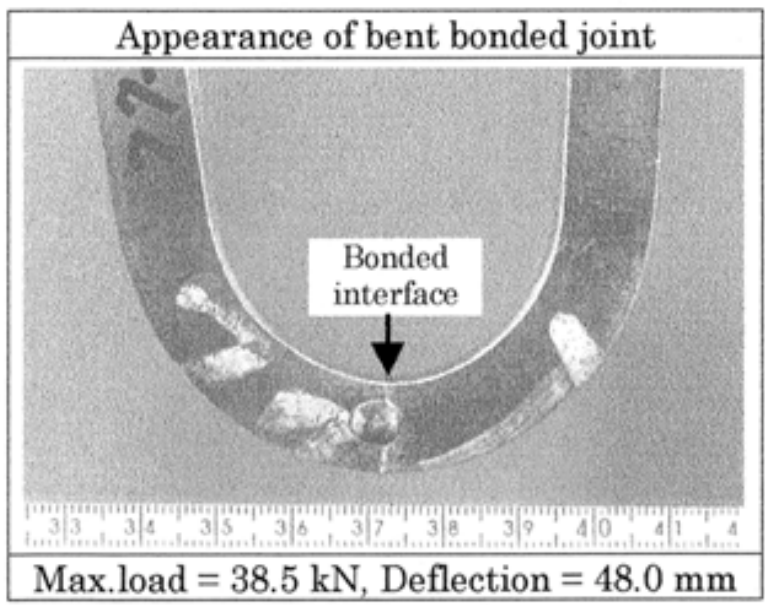

Base metal : Max.load $=49.4 \mathrm{kN}$,

Deflection $=47.0 \mathrm{~mm}$

Fig. 9. Appearance of bent bonded joint of duplex stainless steels.

\section{2 .3 接合部の硬さ測定結果}

二相ステンレス鋼接合部の硬さ分布測定結果を Fig.10 に示す . 接合界面を挟んだ約 $150 \mathrm{~mm}$ の範囲で硬さは母材 よりも低下し, 接合界面に近いほど, 兴の軟化の程度が大 きくなる傾向を示した .

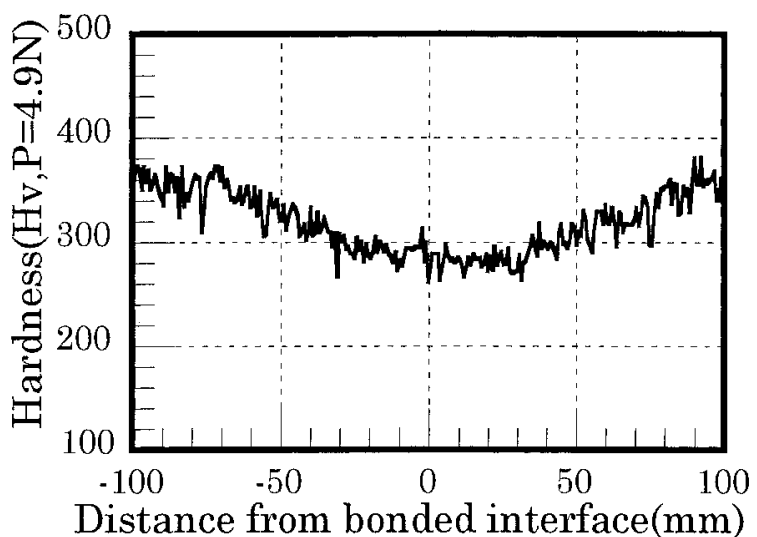

Fig. 10. Hardness distribution of bonded joint of duplex stainless steels.
3.2 .4 熱影響部のシャルピー衝撃試験結果

二相ステンレス鋼接合継手の熱影響部のシャルピー衝 撃試験結果を Table 7 に示す . いずれの試験温度において も熱影響部の吸収エネルギーは非常に低い値を示した.後 熱処理 (1100 ${ }^{\circ} \mathrm{C} \times 900 \mathrm{~s}$ 水冷) により熱影響部の衝撃特性 は母材同等レベルまで回復した .

Table 7. Results of charpy impact test of HAZ and postheat-treated HAZ.

\begin{tabular}{c|c|c|c|c|c}
\hline \multirow{2}{*}{ Specimen } & \multicolumn{5}{|c}{ Absorbed energy (J) } \\
\cline { 2 - 6 } & $-40{ }^{\circ} \mathrm{C}$ & $-20^{\circ} \mathrm{C}$ & $0{ }^{\circ} \mathrm{C}$ & $20{ }^{\circ} \mathrm{C}$ & $40^{\circ} \mathrm{C}$ \\
\hline Base metal & 40 & 51 & 92 & 212 & 275 \\
\hline HAZ(as-bonded) & 6 & 6 & 6 & 8 & 12 \\
\hline $\begin{array}{c}\text { Post heat-treated } \\
\text { HAZ }\end{array}$ & 40 & 47 & 90 & 224 & 285 \\
\hline
\end{tabular}

\section{2 .5 接合部の内質調査結果}

二相ステンレス鋼接合部のミクロ組織観察結果を Fig.11に示す . 接合界面 , および, 熱影響部には割れなど の欠陥は認められなかった．また，接合界面を挟んだ約 $20 \mathrm{~mm}$ 範囲でフェライト相およびオーステナイト相の圧 延組織は消失していた 接合界面から約 $50 \mathrm{~mm} 〜 60 \mathrm{~mm}$ 離 れた部位においてはフェライト相とオーステナイト相の 境界に析出物が観察され, 抽出残さのX線回折結果から， Fig.12に示すように,析出物はX 相および $\mathrm{M}_{7} \mathrm{C}_{3}$ 炭化物で あることが確認された .

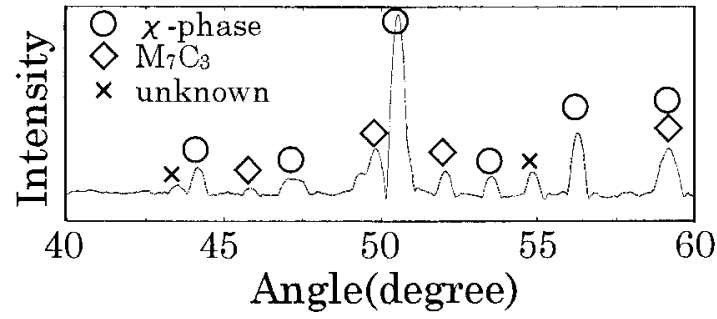

Fig. 12. Diffraction pattern of X-ray of precipitates in HAZ.

\section{3 接合継手の腐食試験試験結果}

二相ステンレス鋼接合継手の4点曲げ応力腐食割れ試験 の結果を Table 8 に示す . 接合部，および, 熱影響部の腐 食速度は母材とほぼ同等であり，ピットや割れは認められ 

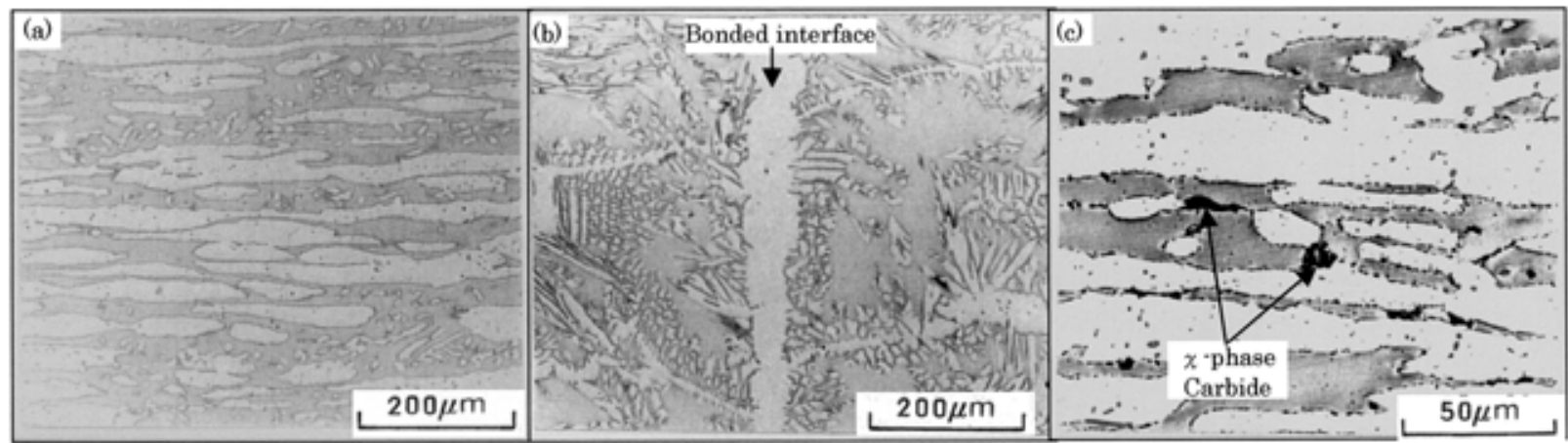

Fig. 11 . Microstructures of bonded joint of duplex stainless steels. (a) Base metal. (b) Bonded interface. (c) HAZ (50mm from bonded interface).

\section{なかった}

二相ステンレス鋼接合継手の局部腐食試験結果をTable 9 に示す . 接合部の腐食速度は母材と同等であり，ピット などの侵食は観察されなかった .

Table 8. Results of four point bending stress corrosion cracking test of bonded joint of duplex stainless steels.

\begin{tabular}{c|c|c}
\hline Specimen & $\begin{array}{c}\text { Corrosion rate } \\
\left(\mathrm{g} / \mathrm{m}^{2} \mathrm{hr}\right)\end{array}$ & Failure/No failure \\
\hline \multirow{2}{*}{ Base metal } & 0.0012 & No failure \\
\cline { 2 - 3 } & 0.0007 & No failure \\
\hline Bonded joint & 0.0011 & No failure \\
\cline { 2 - 3 } (bonded interface) & 0.0010 & No failure \\
\hline \multirow{2}{*}{$\mathrm{HAZ}$ (as-bonded) } & 0.0010 & No failure \\
\cline { 2 - 3 } & 0.0011 & No failure \\
\hline
\end{tabular}

Table 9. Results of localized corrosion test of bonded joint of duplex stainless steels.

\begin{tabular}{c|c|c}
\hline Specimen & $\begin{array}{c}\text { Corrosion rate } \\
\left(\mathrm{g} / \mathrm{m}^{2} \mathrm{hr}\right)\end{array}$ & Failure/No failure \\
\hline \multirow{2}{*}{ Base metal } & 0.0019 & No failure \\
\cline { 2 - 3 } & 0.0020 & No failure \\
\hline $\begin{array}{c}\text { Bonded joint } \\
\text { (bonded interface) }\end{array}$ & 0.0022 & No failure \\
\cline { 2 - 3 } & 0.0019 & No failure \\
\hline
\end{tabular}

\section{4 接合部の非破壞検査}

反射法を用いた二相ステンレス鋼接合部の超音波探傷 結果では，接合部に反射エコーは認められず, 弚の接合部 のミクロ観察においても欠陥は認められなかった .

一方，透過法を用いた超音波探傷結果では，Fig.13 に示 すように，接合部を透過する超音波強度が減衰するほど二 相ステンレス鋼接合継手の引張強さが高くなる傾向が認 められた .

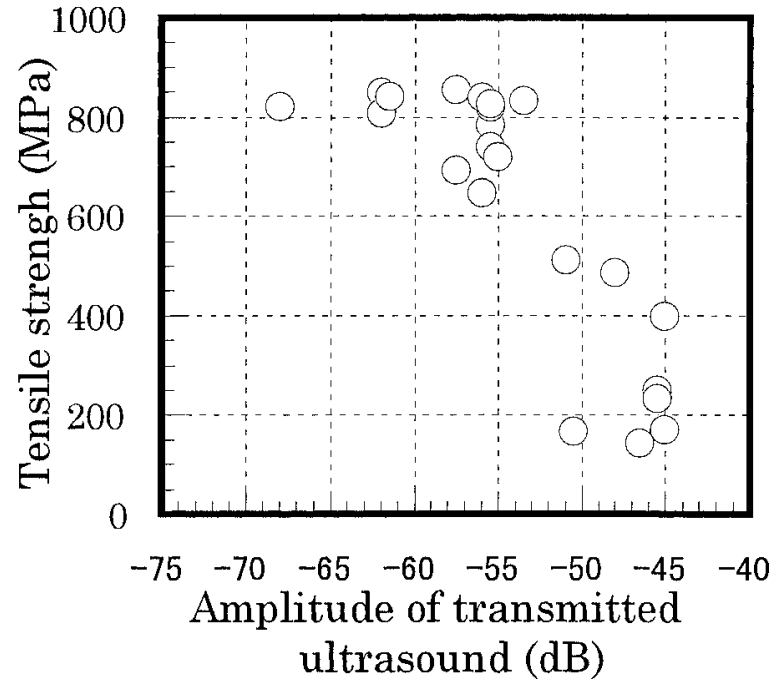

Fig. 13. Relationship between tensile strength of bonded joint of duplex stainless steels and ultrasonic energy passed through bonded zone.

\section{4. 考察}

\section{1 接合継手強度向上の要因}

目的変数を引張強さ, 説明変数を接合温度, 保持時間, 接合圧力 , および, 接合面粗さとして , 二相ステンレス鋼 接合継手の引張強さに及ぼす接合条件の影響について重 回帰分析を行った .二相ステンレス鋼接合継手の引張強さ に及ぼす影響が最も顕著な接合パラメータは接合温度で あった (危険率 $1 \%$ で有意)．重回帰式を式 (1)に示す．

接合継手の引張強さ $(\mathrm{MPa})=2.80$ • 接合温度 $\left({ }^{\circ} \mathrm{C}\right)-0.754 \bullet$ 保持時間 $(\mathrm{s})-54.03$ ・接合圧力 $(\mathrm{MPa})+0.738$ ・面粗度 $(\mu \mathrm{m})$ $-2590$

接合温度が高いほど接合継手の引張強さは増加する回 帰係数を示したが, 接合温度が $1250^{\circ} \mathrm{C}$ 以下では引張強さ 
は低かった .Fig. 14 に示すように低い温度 $\left(1200{ }^{\circ} \mathrm{C}\right)$ て接 合した継手の接合界面には窒化ボロン (BN) がEPMAより 観察され，引張強さの低下の原因として，接合界面におけ る室化ボロン (BN) の多量な析出が考えられる.破壊のメ カニズムは室化ボロン $(\mathrm{BN})$ が破壞の起点となり，室化ボ ロン (BN) に沿って破壞が伝播したと考えられる．一方， 接合温度の高いもの $\left(>1250{ }^{\circ} \mathrm{C}\right)$ では, ボロンは均一に 拡散されており，窒化ボロン (BN) は形成されていない この室化ボロン $(\mathrm{BN})$ は二相ステンレス鋼に室素が多く含 まれていることから，二相ステンレス鋼の室素とインサー ト材のボロンにより生成したと考えられる .

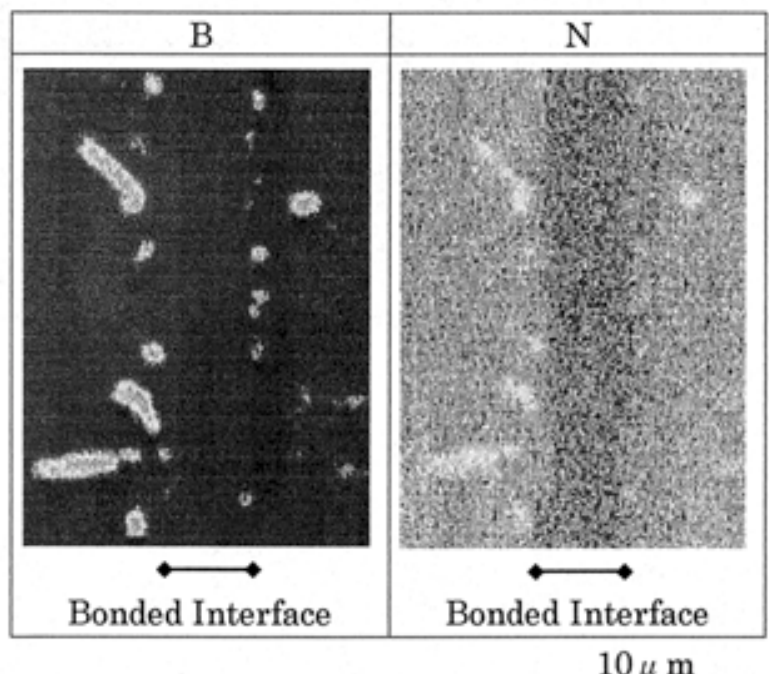

Fig. 14. Result of EPMA at bonded interface of duplex stainless steels (Elements : B, N).

\section{2 接合継手の諸特性について}

4.2 .1 接合継手の熱影響部のシャルピー衝撃特 性について

二相ステンレス鋼溶接継手の熱影響部と同樣に，二相ス テンレス鋼接合継手の熱影響部のシャルピー衝撃特性が 著しく低下したのは熱影響部にX 相が析出したことが原 因であると考えられる 従って 接合継手に後熱処理 (1100 ${ }^{\circ} \mathrm{C} \times 900 \mathrm{~s} \rightarrow$ 水冷) を施すことによりX 相が母相に固溶さ れ，衝撃特性が母材同等レベルまで回復したと考えられ る。

\section{2 .2 接合継手の耐食性について}

二相ステンレス鋼接合継手の熱影響部に $\mathrm{M}_{7} \mathrm{C}_{3}$ 炭化物 ${ }^{3)}$ が析出したが, 腐食特性低下の最大の原因である $\mathrm{M}_{23} \mathrm{C}_{6}$ 炭 化物が析出していないため,本実験の腐食試験において割 れやピットは観察されなかったと考えられる．

\section{3 接合強度と超音波強度の関係}

目的変数を超音波透過強度, 説明变数を接合温度, 保持 時間, 接合圧力, 接合面粗さとして, 超音波透過強度に及 ぼす接合条件の影響について重回帰分析を行った .二相ス テンレス鋼接合部の超音波透過強度に及ぼす影響が最も 顕著な接合パラメータは接合温度であった（危険率 $1 \%$ で 有意)．重回帰式を式 (2)に示す。

超音波透過強度 $(\mathrm{dB})=-0.0539$ - 接合温度 $\left({ }^{\circ} \mathrm{C}\right)-0.00868$ 保持時間 $(\mathrm{s})+1.09$ - 接合圧力 $(\mathrm{MPa})+0.0507$ - 面粗度 $(\mu \mathrm{m})+8.50$

接合温度が高いほど超音波透過強度が減少する傾向を 示唆している. 弚の原因として, 接合温度が高いほど, 接 合界面近傍の圧延組織が消失し, 結晶粒粗大化による超音 波の散乱 ${ }^{9)}$ が生じ，超音波透過強度が減少したと考えら れる。

超音波透過強度は接合温度と相関か強く, 接合継手の引 張強さも接合温度と強い相関があるので, 超音波透過強度 と接合継手の引張強さに相関性が得られたと考えられる． 従って, 超音波試験法を用いることにより, 非破壤て接合 継手強度を推定することが十分可能であると考えられる．

\section{5 . 結 論}

本開発で以下の結論を得た。

(1) 接合温度が低い場合 $\left(<1250{ }^{\circ} \mathrm{C}\right)$, 室化ボロン $(\mathrm{BN})$ が接合界面に析出し，接合強度が極めて低下した。一方， 接合温度が高い場合 $\left(>1250{ }^{\circ} \mathrm{C}\right)$, 接合界面に窒化ボロン (BN)の析出がなくなり，界面強度が向上した．

(2) 接合時の加熱により，熱影響部にX 相が析出し，衝撃 特性が著しく低下した.しかし, 後熱処理 $\left(1100^{\circ} \mathrm{C} \times 900 \mathrm{~s}\right.$ ＼cjkstart水冷）を施すことにより X 相を母相に固溶させ，衝撃 特性は母材同等レベルまで回復した .

(3) 4 点曲げ応力腐食割れ試験および局部腐食試験におい て，接合部の腐食速度は母材同等であり，ピットや割れな どの欠陥は観察されなかった .

（4）接合部を透過する超音波強度と接合継手の引張強さに 相関があり，接合継手強度を非破㗒で推測することが可能 である

(5) 適正な条件で接合された二相ステンレス鋼液相拡散接 合継手の機械特性および腐食特性は良好で, 液相拡散接合 法の適用の可能性を確認した . 


\section{(文 献)}

1)小笠原, 神山，丸山: 製鉄研究, 328(1988), 22.

2)三牧, 高田, 矢崎: 製鉄研究, 329(1988), 48.

3)小川 ,小関: 溶接学会誌, 57(1988), 92.

4)小川, 岡本 植田: 住友金属, 46 (1994), 80.

5)佐々木 北野, 中島: 住友金属, 48(1996), 51 .

6)谷口 加藤: 自動車技術, 49-11 (1995), 37.

7)藤堂ら: 日経メカニカル, 504(1997), 48.

8)日本土木学会: 鉄筋のアモルファス接合継手設計施工指 針(案), (1994).

9)R.Yamada ,T.Shimizu „H.Horio: Materials Evaluation , 59 (2001), 131 . 